\title{
Use and Appropriation of Virtual Social Networks: Mexico and Spain, a Cross-Cultural Study
}

\author{
Salvador Madrigal Moreno ${ }^{1}$, Jaime Gil Lafuente ${ }^{2}$, Gerardo Gabriel Alfaro Calderón ${ }^{1}$ \& Flor Madrigal Moreno ${ }^{1}$ \\ ${ }^{1}$ Department of Accounting and Administrative Sciences, Universidad Michoacana de San Nicolás de Hidalgo, \\ Morelia, México \\ ${ }^{2}$ Department of Economics and Business Organization, Universidad de Barcelona, Barcelona, Spain \\ Correspondence: Salvador Madrigal Moreno, Department of Accounting and Administrative Sciences, \\ Universidad Michoacana de San Nicolás de Hidalgo, J. Mújica Avenue S/N, Morelia, Michoacán, México. \\ E-mail: smadrigal@umich.mx
}

Received: November 8, 2016

Accepted: December 3, 2016 Online Published: January 16, 2017

doi:10.5539/ijms.v9n1p82

URL: http://dx.doi.org/10.5539/ijms.v9n1p82

\begin{abstract}
Virtual social networks (VSN) represent a phenomenon that continues reconfiguring the social dynamics. They have gone from the embryonic stage to a stage of maturity where it is observed that the context uses and appropriates those considered useful, giving them the use that seems to fit. Thus, Mexico and Spain contexts have specific characteristics and conditions. The aim of this study is to describe the access and appropriations of VSN, both in Mexico and in Spain and to show the challenges they face. The structure of this research is primarily an introduction to explain social networks as a current media phenomenon to later compare how each context has accessed, used and fitted these social networks into their own contexts. Finally, it will be discussed how Spain and Mexico face their challenges and last how each country treat the social media either as a threat or as an opportunity.
\end{abstract}

Keywords: virtual social networks, access and appropriation, interaction, ICT

\section{Introduction}

Virtual social networks (VSN) is a social phenomenon that needs to be studied, due to more than one-third of Internet users in the world, and more than one-sixth of the global population immersed in this phenomenon (Hofacker \& Belanche, 2016). If the VSN are properly used, they can represent a great opportunity to organizations. Otherwise, they might represent a significant threat to these same organizations.

Additionally, the World Economic Forum in their 2016 report states that a new economy is emerging, in which the information and communication technology (ICT), and VSN (as a ludic part of the ICT), have taken a relevant role. However, research is needed to guide the development of government policies and regulations to those involved in this subject. As the new digital economy is shaping itself, it is required to provide then an appropriate guidance to ensure its sustainability (WEF, 2016).

This study tends to establish the particularities of Mexico and Spain concerning the access, use and appropriation of VSN, and the necessity of designing and establishing specific strategies for each of the mentioned contexts. The intention of this research is to clarify the myths and realities about the universality of social networks. The data used in this study regarding to the use of social networks in Mexico was retrieved from the National Institute of Statistics and Geography (INEGI), the Federal Telecommunications Institute (IFT), the Mexican Internet Association (AMICI), the World Bank and from a series of academic publications on the use of VSN in Mexico. The data that explains the Spanish context was withdrawn from the publications of the National Statistics Institute (INE), the reports filed by the Interactive Advertising Bureau (IAB Spain), Telefónica Foundation and various other studies from researchers and specialists in this area. As mentioned latter, the aim of this research is to show the accessibility and use of VSN in Mexican and Spanish contexts and the challenges they face. This study might help to determine the communication and interaction practices which are involved in the communication process of the ICT. Also, this study will include a revision of a Network Readiness Index presented by the World Economic Forum which refers in peculiar to the accessibility and infrastructure in these two countries. 
This paper is structured as follows: first, a review of VSN literature. Next, an analysis of the use of the VSN in Mexico and Spain is presented. Subsequently, a comparative analysis of the VSN in Mexico and Spain is discussed. Finally, in the conclusion a summary of the challenges faced by both countries as well as future investigations will be presented.

\section{Method}

This is a documentary, descriptive research which is based on data retrieved from official agencies in Mexico (INEGI and IFT) and Spain (INE) and the Network Riability Index 2016 (NRI) reports presented by the World Economic Forum. This research also documents information from ICT organizations on the accessibility and use of the Internet like the Mexican Internet Association (AMIPCI) and the IAB Association Spain, Telefonica Foundation, as well as different specialized websites on the use of internet such as World Stats, comScore and Statista and academic publications on the VSN in both countries. Based on all the data collected, the VSN is presented as a contemporary phenomenon that reconfigures many of the social activities and, because of its dynamic nature, the importance of having up-to-date information.

\section{The Information Society and Social Network Configuration}

Although social networks have existed since the very configuration of human interaction, at this time it is relevant to establish their reconfiguration from digitization as an element of the Information Society (IS). This is how virtual social networks (VSNs) represent a contemporary element of social reconfiguration.

The term information society (IS) was introduced by the sociologist Daniel Bell (1973) and was subsequently embraced by Thomas Friedman in 2005 who performed an analysis on how society has evolved to a stage where the management, treatment, and possession of information is crucial for social development (Arellano-Toledo, 2012). However, some researchers refer to Japanese sociologist Yoneji Masuda, who published in 1968 a book named An Introduction to the Information Society and years later the information society as post-industrial society where Masuda (cited in Arellano-Toledo, 2012) defines the IS as society which grows and develops around information, permitting the flourishment of human intellectual creativity, rather than just an increase-on material consumption.

Arellano (2012, p. 45) defines the IS as the society which uses the ICT to promote the development of the sectors that conform the society (government, companies, etc.), enhances their activities and obtains the greater benefit of the information to convert it into knowledge and thus to move towards an Information Society and (if it generates) the Knowledge (Information and Knowledge Society, IKS).

This is a society where the creation and dissemination of knowledge are the key elements between individuals (De la Antonia, 2009). Peter Drucker also (in Esteinou \& Alva de la Selva, 2011) pointed the transition from the industrial society to the IS. Drucker observed that the so-called ICT revolution was, in fact, a revolution of knowledge.

Manuel Castells (2011) argues that the concept of IS only reproduces the myth of the historical evolution from the nomadic society to an agricultural society and then to the industrial society which culminates in the ISI. Castells conceives a network society rather than an SI. Interconnected nodes forming networks are enhanced by ICT structure the network society.

On the Information Society context, the ICTs represent the social element of reconfiguration. ICTs have changed the dimensions of social and organizational life that seemed immutable, as time, space (Chang, Shen, \& Liu, 2016) and even the perception of reality (Esteinou \& Alva de la Selva, 2011). The significant appropriation of mobile devices, such as mobile phone, is now a fact.

The ICTs represent the innovation in the field of digital technologies. They represent the microelectronics, information technology, telecommunications, mobile communication devices, which have been massively incorporated into the economic activities (De la Antonia, 2009). In fact, the economic and financial relationships between suppliers and customers are highly dependent on the network that can be configured from ICT. The application of ICTs through mobile devices and the development of applications (Apps) worldwide, represent a new and a very powerful tool (Caicedo, Acuña, Rodríguez, \& Wellington, 2016). Within ICTs is the smartphone device which has introduced the more significant and substantial changes (Scolari, Güere, Kuklinski, Medina, \& Clemente, 2010); from the pocket is the prosthetic screen that provides permanent and ubiquitous access to the digital world (Reig, Dolors, \& Vílchez, 2013, p. 12). Therefore, mobile technology has given individuals such mobility that at times interferes with, work, family, etc. (Esteinou \& Alva de la Selva, 2011; Niño, Luisa, \& Llorente, 2014).

The inclusion of ICT in the principal activities of society has generated a global structural change in consolidated 
work systems, which also implies a significant effort by every social organism to adapt to the new production processes with everything that this entails: technological reconversion, professional retraining, the creation of new professional profiles and, in short, an entire adaptation and reorganization not only of products and contents but also of the ways of working and to the organizational structure itself (Jódar, 2009).

Thanks to available ICT the interaction and the social organization have changed and keep changing. However, the great challenge has been and continues to be the digital gap. The digital divide is the construct used to refer to dissimilarities in utilization and knowledge of information technology and digital communication and the development of the information society (Llorca Abad, 2012). The digital gap can be identified in the first place by the availability of telecommunications and networks infrastructure, secondly to the accessibility (related to the scope of the user's financial budget) and in the third place to the possession of skills and knowledge to make proper use of technology.

The technological revolution that has marked the development of the ICTs has also become a kind of cultural revolution establishing new lifestyles, behaviors, and forms of communication and interaction (Aguilar, 2016; Krishnan \&Lymm, 2016); in fact, the ICTs create and redefine cultural ways of living (Jódar, 2009). It is important to mention that young people are the ones who have been the focus of research on the appropriation of ICTs more specific on the use of the mobile phone and their connection complicity to be present in the VSN (Fonseca Mantilla, 2015; Almansa, Fonseca, \& Castillo, 2013; Chang et al., 2016; Islas, 2015; González Hernández, 2015; Reig, Dolors, Vílchez, 2013; Kim, 2014; Chamarro, Bertran, Oberst, \& Torres-Rodríguez, 2016; Hidalgo, 2016; Niño et al., 2014). This means that for young people, the media, and the new technologies are not simply symbolic supplies or indications of distinction, but important networks in the definition and distribution of cultural knowledge (Urteaga in Hidalgo, 2016).

The massive use of the ICTs facilitated the emergence and positioning of VSN. VSNs have brought with them a challenge, which is to develop and carry out strategies to take advantage of the opportunities and to consider the challenges that these technologies offer (Artopoulos, 2011).

Summarizing, social networks are as old as human beings but acquire a new social, cultural and political, organizational dimension in the techno-social environment of the digital age (Campos Freire, 2013). VSNs are social technologies derived from Web 2.0 that allow the generation of virtual communities from the connection, production, interaction and information exchange of an unlimited group of people who share interests in common (Criado \& Rojas-Martín, 2016), who keep interactions amongst individuals that are geographically dispersed around the world (Krishnan \& Lymm, 2016), for instance, communicative structures, connected and potentialized through the internet (Castells, 2009).

VSNs have become platforms for communication and social interaction that have forced traditional media (press, radio, and television) and business companies to seek for alternatives that allow them to interconnect with users in the new communication ecosystem (Campos Freire \& Rúas Araújo, 2015, p. 14). As has been observed, the development social dynamics, information and communication technologies have had an enormous impact on the contemporary society:

The hypermedia web revolution (1990-93) occurred at the end of the twentieth century, allowing the navigation and the interconnection through the Internet. The first ten years of the new 21 st century permitted the mass self-communication (the social Web 2.0 and digital networks) that permitted the self-creation and global dissemination of messages 15 (Castells, 2009, p. 88). On the second decade of the 21 st century is the one known as Internet of Things (Web 3.0, data automation and communications with objects). The third decade will be the one of semantic interpretation, robotization, biotechnology and artificial intelligence (the Web 4.0 will release more human attention from routine tasks and processes) (Campos Freire \& Rúas Araújo, 2015, p. 16).

The VSNs have been for a few years a mass phenomenon (Lorenzo-Romero, Gómez-Borja, \& Alarcón-del-Amo, 2011) and have become the central paradigm of the online media ecosystem (Campos Freire \& RúasAraújo, 2015). The emergence of the Internet changed the media ecosystem and the way in which the relationships to the media are given (Canavilhas, 2011). This happended basically because of the appropriation of the mobile phone (Chang et al., 2016; Niño et al., 2014; Reig, Dolors, \& Vílchez, 2013); the mobile phone \& Facebook combo has made the smartphone the device for the production and consumption of cultural goods (Artopoulos, 2011).

More than just simply a means of communication, the VSNs represent ecosystems (a unit composed by an organization of relations or chains of interdependencies that share the same habitat) of social relations. That is, they allow communication and sociability to be observed from an interdisciplinary perspective (Campos Freire, 2013), the challenge still pending. For this reason, it is convenient and pertinent to investigate the link between 
man and VSNs in every historical and cultural context (Ceballos González \& Marreno Santana, 2016), since the impact of VSNs will depend on its appropriation, consequently creating a sociocultural significance to each reality. Although culture is a product of the interaction of individuals in society, the VSNs are reconfiguring these relationships. VSNs are environments in which viral contents, memes, and other symbolic forms flow and whose social uses need to be analyzed (Pérez Salazar, 2016). Also, its use has increased exponentially generating changes in the communicative and social dynamics of the individuals who are seeking for immediate interaction (Sánchez Torres \& Arroyo-Cañada, 2016).

\subsection{The ICT Infrastructure and Global Access}

The Global Information Technology Report 2016 (WEF, 2016) from the World Economic Forum establishes through the Network Reliability Index (NRI) the conditions for participating in the fourth industrial revolution through the access of Information and the use of the digital technology of those countries that are part of the Organization for Economic Co-operation and Development (OECD). In the first place, it emphasizes the importance of the ICTs as the backbone in the processes of innovation in the digital economy. The NRI is based on ten pillars: political and regulatory environment, business and innovation environment, infrastructure, accessibility, skills, individual use, business use, government use, economic impact and social impact. For the present study the most important pillars are accessibility and individual use.

Based on the Global Information Technology Report, Europe has seven of the ten countries with the greatest network availability worldwide. America only has the United States in the top ten. Mexico occupies the eighth place in comparison to other the countries in Latin America and the Caribbean. Spain ranks 35 (34 in 2015) and Mexico 76 (which has come down seven places compared to 2015) (WEF, 2016).

The report highlights that Mexico has increased the individual use of the broadband (although it also indicates the high costs that impact the digital divide), and the growth in the implementation of ICTs by the government as well as in business (WEF, 2016, p. 30). About Spain they emphasize the accessibility, as well as the governmental use (WEF, 2016, p. 173).

On the other hand, the Internet statistics website, Internet World Stats (IWS, 2016) allows users to know the usage and access from a global or individual perspective. To this website, Europe has a population of $832,073,224$ inhabitants which represents the $11.3 \%$ of the world's people, from whom $614,979,903$ are Internet users, representing a penetration of $73.9 \%$.

Latin America and the Caribbean (where Mexico is included) have a population of 626,054,392 inhabitants, representing the $8.5 \%$ of the world population. From whom, 384,751,302 have access to an internet connection which represents an inclusion of the $61.5 \%$.

Spain has a population of $48,563,476$ of which $37,865,104$ are internet users. In other words, Spain has a digital penetration of 78\%; it also has 22,000,000 Facebook accounts. 47.4\% of Internet users in Spain have a presence on Facebook. On the other hand, Mexico counts on a population of 123,166,749 inhabitants of which 69,000,000, $56 \%$ have access to an internet connection and has 69,000,000 Facebook accounts.

\subsection{Information and Communication Technologies and Virtual Social Networks in Mexico}

The Mexican context presents an interesting scenario on ICT and VSN. This study highlights the importance of internet availability, as well as a connection terminal (computer, tablet or mobile phone, TV, etc.) and what activities are carried out on the Internet and VSN in Mexico. According to the Institute of Statistics and Geography (INEGI, 2014) and the Federal Institute of Telecommunications (IFT, 2016) in Mexico, 45 out of every 100 homes have computers, but there are 89 mobile phones per 100 Mexicans.

The NRI states that in Mexico the level of use of the VSNs for personal and professional practices stands below the median of the OECD countries (WEF, 2016). On the other hand, the 12th Study on the Habits of Internet Users in Mexico 2016 conducted by the Mexican Internet Association (AMIPCI, 2016), indicates that there are 65 million of Internet users in Mexico. 50\% are men, and 50\% are women while the IWS establishes that the number of Internet users would reach the number of 69 million by June 2016 (IWS, 2016). In 2015 a study shows that there was a penetration of the 57.4\% (World Bank, 2016) but by 2016 already exceeds the 59\% penetration among the population of 6 years or more in Mexico (AMIPCI, 2016). The daily average connection time is 7 hours and 14 minutes. The report shows that $87 \%$ Mexican internet users normally get connected from home $52 \%$ from a mobile device and $38 \%$ from work. The penetration and positioning of mobile devices have increased the internet connection in a $17 \%$ compared to the previous year. The connection through the mobile devices is mainly done by using the mobile phone, since $77 \%$ of Mexican Internet users are connected by their smartphone. Finally, Mexico ranks 11th among the countries with the highest number of Internet users in the 
world (WIP, 2013).

A report from the AMIPCI shows that the main use of internet by users is to connect to social networks, followed by sending emails and third is to send and receive instant messages. Social networks have been positioned as the most accomplished activity by Mexican Internet users. Therefore, there is an excellent opportunity to take advantage of digital inclusion in Mexico. The government and organizations have the conditions to develop communication and marketing strategies in such a way that creates a valuable relationship between government and citizenship and the organization with clients.

On the other hand, the Mexican web surfers have a greater presence in social networks. On average, Mexicans are enrolled in at least five social networks. Regarding which is the social network with a greater presence in Mexico, Facebook is used by the $92 \%$ of internauts. Therefore, Mexico occupies the 5th place in the world amongst the countries with the largest presence on Facebook (Statista, 2016). The second most popular social network in Mexico is What's App and the third YouTube, with $79 \%$ and $66 \%$ users respectively (AMIPCI, 2016). $45 \%$ of internet users follow a brand on social networks (WIP, 2013). Now that the mobile phone has become the most popular device to connect to the Internet, also the mobile applications have increased their importance. In Mexico, according to the study conducted by com. Score, and IMS Internet Media Services (IMS, 2016), users have an average of 20 applications installed on their phones, and $79 \%$ have made an online purchase through the mobile phone.

On their latest report, the World Internet Project (WIP, 2013) states that Internet users spend an average of 41.3 hours a week connected to the internet, which far exceeds their exposure to traditional media such as radio, television or the press. This has brought a reconfiguration in the distribution of advertising investment and direct marketing. Also, the Internet has positioned itself as the main means of entertainment and information. Another important element to consider before the positioning of the Internet as a means of communication and information is that the exponential growth of mobile devices has led to the emergence of multitasking; that is, mobile devices have allowed users to be in front of a media and Internet simultaneously.

\subsection{Information and Communication Technologies and Virtual Social Networks in Spain}

From the data presented by the World Bank (2016) about users in the world, 78\% of the Spanish population accesses the internet, and $81 \%$ uses the VSN, that is, more than 15.4 million of VSN users (IabSpain, 2016). The 2016 Annual Social Networks Survey, conducted by IabSpain, highlights that WhatsApp users increase and that Facebook, WhatsApp, and Twitter are the most well-known VSNs. The study also states that Facebook and WhatsApp are the most liked VSN with a $76 \%$ of preference. Also, the Internet is becoming more and more popular with spaniards, as $64.3 \%$ of the population uses the internet every day (INE, 2015).

Concerning to the frequency of use, it stands out that WhatsApp, Spotify, and Facebook are the most used VSN with a frequency of use greater than 4 hours a week. About the use that is given to the VSN, it was found that the three most popular activities are sending messages or chatting with a $79 \%$, watching videos or listening to music $57 \%$, seen what contacts are doing $48 \%$. The main use sticks to social activities (Fundación Telefónica, 2015). An aspect that needs to be remarked in the Spanish case is that the $85 \%$ of Internet users declare to be influencers followers, particularly on Facebook (63\%). Also, $81 \%$ use Facebook to follow brands that refer to culture, technology and fashion for men; and culture, fashion, and beauty for women. On the other hand, $80 \%$ of users accept advertising from the VSN (IabSpain, 2016).

About the way people connect to the internet, the $94 \%$ connect via PC, the $91 \%$ through the telephone and the $28 \%$ through a tablet. More than $66 \%$ of Spanish Internet users use more than one device to connect to the internet. About the number of applications used by Spanish population, the average number of applications installed on smartphones is 39 (Fundación Telefónica, 2015). Another relevant aspect of the Spanish context is that the 74\% of Internet users stated that they were influenced by VSN, particularly by Facebook (Fundación Telefónica, 2015), to make a purchase and the $14 \%$ said to have bought something through a VSN (IabSpain, 2016).

Other uses of the Internet in Spain, refer to participation in social networks, electronic commerce and interaction between people and the public administration (63.4\% of users have used the network to manage a public service) (Fundación Telefónica, 2015). The phenomenon of VSN has generated different investigations in this issue. In a research carried out by Criado \& Rojas-Martín (2016), they describe that there is a high adoption of VSNs in the municipalities of Spain; the $99.2 \%$ of municipalities with more than 50,000 inhabitants in Spain have at least one VSN. Also, the $84.9 \%$ use VSNs as a management tool. However, only the $29.8 \%$ of municipalities have a formal strategy. Besides, there has not been an institutionalization of ICT within the organizational structures of municipalities yet, much less there has not been considered an administrative role strategy, material resources, and skilled people. 
On the other hand, Spanish consumers use more VSN to keep them informed, to complain about a brand, exchange experiences, etc. This represents an opportunity to grow to every organization, but also a challenge since the implementation of social networks in the communication and marketing strategy must respond to consumer behavior, business models and the capacity of the organization for establishing the needed strategies (Hofacker \& Belanche, 2016; IabSpain, 2016). The incorporation of ICT in the substantive activities of the organizations has forced the managers to observe the VSN given their penetration in the market. This has led the VSN to keep their growth and, as a consequence, some organizations use the VSN as the main channel of communication (Hofacker \& Belanche, 2016). Geolocation is the characteristic of the mobile phone that is producing a great convergence between mobile e-commerce and social networks (Fundación Telefónica, 2015). The most relevant data of the digital context in Mexico and Sapain are shown in Table 1 below.

Table 1. Digital inclusion and VSN in Mexico and Spain

\begin{tabular}{lll}
\hline Mexico & & Spain \\
\hline Population & $123,166,749$ & $48,563,476$ \\
Internet users & 69 millions & 37.8 millions \\
Digital inclusion & $59 \%$ & $78 \%$ \\
VSN users & $79 \%$ & $81 \%$ \\
Facebook subscribers & $69,000,000$ & $22,000,000$ \\
Devices of conection & $93 \%$ (mobile phone or tablet) & $94 \%$ PC \\
& $77 \%$ mobile phone & $91 \%$ mobile phone \\
Principal activity of the internet users & $69 \%$ laptop & $28 \%$ tablet \\
Principal VSN & $79 \%$ use VSN & $79 \%$ send messages or chat \\
& 1. Facebook & $1 .-$ Facebook \\
Internet users that follow brands on VSN & 2. WhatsApp & 2. -WhatsApp \\
\hline
\end{tabular}

Source: Original from the authors. Adapted from AMIPCI (2016), INE (2016), INEGI (2016), IWS (2016) IabSpain (2016) and WIP (2013).

\section{Discussion}

The societies both in Mexico and Spain have adopted ICTs more for VSN reasons than any other use. The incorporation of ICTs in the substantial and economic activities of a nation will be decisive for its innovation and economic processes (WEF, 2016). However, each nation presents a context since the same conditions do not exist. To establish the similarities and differences, in between Mexico and Spain, allows us to know the challenges they both have faced. In addition, a diagnosis can be established that guides and defines public policies (Islas, 2015) to each context.

This study confirms that ICT infrastructure (Krishnan \& Lymm, 2016) influences the level of use and largely defines the digital divide. About the results presented by IWS (2016) on digital inclusion, Mexico is below average in Latin America and the Caribbean while Spain is slightly above the average in Europe.

Mexico exceeds Spain about mobile phone rates, while broadband rates have better conditions in Spain (WEF, 2016). Mexico requires strategies aiming to satisfy its users of mobile telephony; this is an opportunity to take advantage of improvements in government management to develop applications that can allow e-goverment operations through the mobile phone, to cite an example, as it happens in Spain.

On the other hand, Spain already has a good evaluation regarding the level of government participation in the use of ICTs for its procedures and services. Therefore, in 2014, it was recognized by the UN for its innovation in e-government, highlighting the opening of public data for its reuse (Fundación Telefónica, 2015). Having the best broadband rate also allows them to increase the possibility of developing more strategies oriented to the development and conformation of Smart Cities (Barcelona and Madrid are already working on it) or the internet for things, and to link them to the VSN. The appropriation in Spain of the mobile phone and the VSN allow them to find in geolocation a great ally.

Although the number of Internet users is greater in Mexico, Spain has a better infrastructure (WEF, 2016), which allows the reduction of the access gap and, in proportion, to maintain greater digital inclusion. Although the mobile phone represents the device that has the greatest penetration in both Mexico and Spain, it is evident the need to incorporate applications that allow deploying strategies of interaction according to each culture.

So far in both countries, the use of VSN for recreational purposes has been emphasized. However, the potential 
they have for developing economic, cultural and even political strategies is very great.

Regarding the use of certain VSN, Facebook remains the most penetrating VSN in both countries. Facebook is the biggest VSN. It even stands out that in both countries the most investigated VSN is Facebook. The Facebook studies stand out on Facebook configuration, the managing of the identity, the characterization of the users, the modalities of use, and the privacy and the revelation of information (Chamarro et al., 2016; Chang et al., 2016).

In relation to the challenges facing both countries, the main challenge now is to bring attention beyond the ludic, to use the VSN for economic, cultural and social development. Although the recreational part was the one that led the users to appropriate the VSN, it is observed that they have already been adopted in a mostly positive way (Criado \& Rojas-Martín, 2016). The perception is changing, because now the VSN is seen more than just a place to chat and is used with functional interactional objectives (Niño et al., 2014).

\section{Conclusions}

The great appropriation made by Mexico and Spain of the VSN forces us to reflect on how incipient is the digital literacy (Almansa et al., 2013). It is also necessary to make a pause and observe that just intensifying the use of the ICTs is not the answer. The case of Mexico is recognized by the NRI regarding availability, but not access. It will be worth to investigate the real level of appropriation that the users of the ICT have regarding to NRI's skills; in this context Mexico faces an enormous challenge in two main areas, education and digital literacy.

VSNs have changed the ways of relating and interacting to individual and social level, consequently, in the structure of any organization. Therefore, the need to design and implement professional profiles that know the dynamics of VSN has been remarked.

The present study confirms that the potential benefits of VSN are being underused (Criado \& Rojas-Martín, 2016). In Mexico the ludic part has been developed while in Spain the ludic part and partially the use of the VSN in business and government procedures. Mexico could learn from the Spanish experience to generate its strategies and to encourage the use of VSN beyond the ludic screen. However, it is the user who will decide how to use VSNs.

It is recommended to extend this research to other cultural and national environments for more robust comparisons. This will allow establishing what new competencies are necessary, especially regarding the use and appropriation of ICT and their environments. Also, research on VSN remains a challenge to be solved (Linne, 2015) as Internet access has been verified and the use of VSNs must be observed from a cultural perspective. Consequently, there will always be conditions regarding the uses and appropriations of VSNs (Ceballos González \& Marreno Santana, 2016) because each context will configure them according to their lifestyle and interaction.

Interdisciplinary research on VSN is required. Human beings have made an extension of their identity, in such a way that the most important relations for them are performing in a mediated way through the VSN: social relations between equals, social procedures, incorporation into circles of interest, cultural development and economic and personal growth, etc. Society has incorporated VSN into its substantive functions. There are still many challenges ahead: the digital divide, digital learning, and digital security the most important.

\section{References}

Aguilar, A. (2016). Identidad y procesos identitarios en la era digital: del intercambio de información a la construcción de sentido. TIC y la reconstrucción de identidades. Reflexiones, análisis y propuestas (pp. 15-52). Coahuila, México: Universidad Autónoma de Coahuila.

Almansa, A., Fonseca, O., \& Castillo, A. (2013). Redes sociales y jóvenes. Uso de Facebook en la juventud colombiana y española. Comunicar, 20(40), 127-135. http://doi.org/10.3916/C40-2013-03-03

AMIPCI. (2016). 12 Estudio sobre Hábitos de los Usuarios de Internet en México 2016. Asociación Mexicana de Internet (Vol. 1). Retrieved from https://www.amipci.org.mx/images/Estudio_Habitosdel_Usuario_2016.pdf

Arellano-Toledo, W. C. (2012). La sociedad de la información en Iberoamérica. Estudio multidisciplinar. México: Infotec.

Artopoulos, A. (2011). La Sociedad de las Cuatro Pantallas: Una mirada latinoamericana. Buenos Aires: Ariel.

Caicedo, C., Acuña, J., Rodríguez, A. D. C., \& Wellington, R. (2016). Aplicativo móvil como estrategia de marketing para el impulso de la matriz productiva en el área de Turismo Mobile. 3Ciencias, 5(1), 41-53. http://doi.org/http://dx.doi.org/10.17993/3ctecno.2016.v5n1e17.41-53

Campos, F. F. (2013). Investigación y gestión de las redes sociales digitales. Tenerife. 
http://doi.org/10.4185/CAC50

Campos, F. F., \& Rúas, A. J. (2015). Las redes sociales digitales en el ecosistema mediático. La Laguna, Tenerife: Sociedad Latina de Comunicación Social. http://doi.org/10.4185/cac92

Canavilhas, J. (2011). El nuevo ecosistema mediático. Revista Index Comunicación, 1, 13-24. Retrieved from http://dialnet.unirioja.es/servlet/articulo?codigo=3660767 $\backslash$ nhttp://hdl.handle.net/10400.6/687

Castells, M. (2009). Comunicación y poder. Madrid: Alianza Editorial.

Castells, M. (2011). La sociedad red: una visión global. Madrid: Alianza Editorial.

Ceballos, G. A., \& Marreno, S. L. (2016). De los medios masivos a las plataformas de comunicación en red. Razón Y Palabra, 92, 1-30.

Chamarro, A., Bertran, E., Oberst, U., \& Torres-Rodríguez, A. (2016). Gestión de la privacidad de los perfiles de Facebook de adolescentes. Píxel-Bit. Revista de Medios Y Educación, 48, 197-208. http://doi.org/10.12795/pixelbit.2016.i48.13

Chang, S. E., Shen, W. C., \& Liu, A. Y. (2016). Why mobile users trust smartphone social networking services? A PLS-SEM approach. Journal of Business Research, 69(11), 4890-4895. http://doi.org/10.1016/j.jbusres.2016.04.048

Criado, I., \& Rojas-Martín, F. (2016). El impacto de las redes sociales digitales en las administraciones locales mitos y realidades en el caso español. Revista de Los Estudios de Derecho Y Ciencia Política (October). http://doi.org/10.7238/idp.v0i20.2581

De la Antonia, D. (2009). Hacia el liderazgo europeo en las escuelas de pensamiento de marketing. Madrid.

Esteinou, J., \& Alva de la Selva, A. R. (2011). Los medios electrónicos de difusión y la sociedad de la información. México: SRE.

Fonseca, M. O. G. (2015). Redes sociales y juventud: uso de Facebook por jóvenes de México, Argentina y Colombia. Universidad de Málaga.

Fundación Telefónica. (2015). La Sociedad de la Información en España 2014. Madid: Ariel.

González Hernández, M. (2015). Las redes sociales y su incidencia en la forma en que los jóvenes se comunican y utilizan la lengua. Perspectiva de los docentes de lenguaje y comunicación. Retrieved from http://repositorio.uchile.cl/handle/2250/136443

Hidalgo, J. (2016). Nuevos medios, nuevas audiencias, nuevos consumidores. Anáhuac University.

Hofacker, C. F., \& Belanche, D. (2016). Eight social media challenges for marketing managers. Spanish Journal of Marketing -ESIC, 20, 73-80. http://doi.org/dx.doi.org/10.1016/j.sjme.2016.07.003

IabSpain. (2016). Estudio Anual de Redes Sociales 2016. Madrid. Retrieved from http:/www.iabspain.net/wp-content/uploads/downloads/2016/04/IAB_EstudioRedesSociales_2016_comple to.pdf

IFT. (2016). Anuario Estadístico 2015. México. Retrieved from http://www.ift.org.mx/sites/default/files/contenidogeneral/estadisticas/anuario-estadistico-2015-acc_1.pdf

IMS. (2016). IMS Mobile in Latam study. Retrieved from http://www.imscorporate.com/news/Estudios-comScore/IMS-Mobile-Study-Septiembre2016.pdf

INE. (2015). Encuesta sobre Equipamiento y Uso de Tecnologías de Información y Comunicación en los $\begin{array}{llll}\text { Hogares } & 2015 . & \text { INE. } & \text { Retrieved }\end{array}$ http://www.ine.es/prensa/np864.pdf/nhttp://www.ine.es/prensa/np933.pdf

INEGI. (2014). Estadísticas sobre disponibilidad y uso de la tecnología de información y comunicaciones en los hogares, 2013. México. $\quad$ Retrieved from http//internet.contenidos.inegi.org.mx/contenidos/productos//prod_serv/contenidos/espanol/bvinegi/product os/metodologias/MODUTIH/MODUTIH2013/MODUTIH2013.pdf

Islas, O. (2015). Cifras sobre jóvenes y redes sociales en México. Entretextos, 1-16.

IWS. (2016). Internet World Stats. Usage and population statistics. Retrieved from http://www.internetworldstats.com/stats.htm

Jódar, J. Á. (2009). La Era Digital: Nuevos Medios, Nuevos Usuarios y Nuevos Profesionales. Razón Y Palabra, 71, 1-11. Retrieved from http://www.razonypalabra.org.mx/N/N71/VARIA/29 JODAR_REVISADO.pdf 
Kim, H. (2014). Whom do you follow?: Examining social distance in Facebook friendship and its influence on brand message adoption. University of North Carolina.

Krishnan, S., \& Lymm, J. (2016). Determinants of virtual social networks diffusion: Insights from cross-country data. Computers in Human Behavior, 54, 691-700. http://doi.org/10.1016/j.chb.2015.07.055

Linne, J. (2015). ¿De qué hablamos cuando hablamos de brecha digital? Questión, 1(46), 151-159.

Llorca Abad, G. (2012). Exclusión digital y límites de la comunicación mediada. Trípodos, 31, 111-123.

Lorenzo-Romero, C., Gómez-Borja, M. Á., \& Alarcón-del-Amo, M. del C. (2011). Redes sociales virtuales, ¿de qué depende su uso en España? Innovar, 21(41), 145-156.

Niño, J., Luisa, G. M., \& Llorente, C. (2014). El Mobile Marketing y las Redes Sociales en el ámbito de los medios publicitarios. (F. García, Ed.). España: Icono 14.

Pérez Salazar, G. (2016). Redes sociales y herramientas para la administración de redes sociales: Definiciones conceptuales desde el campo de la comunicación. TIC y la construcción de identidades. Reflexiones, análisis y propuestas (pp. 53-108). Saltillo, México: Universidad Autónoma de Coahuila.

Reig, D., \& Vílchez, L. (2013). Los jóvenes en la era de la hiperconectividad: tendencias, claves y miradas. Fundación Telefónica. Fundación Encuentro.

Sánchez Torres, J. A., \& Arroyo-Cañada, F. J. (2016). The perception of satisfaction with virtual social networks: A comparative analysis. ESIC Market Economics and Business Journal, 47(1), 131-143. http://doi.org/10.7200/esicm.153.0471.4

Scolari, C. A., Güere, H. N., Kuklinski, H. P., Medina, I. G., \& Clemente, J. S. (2010). Marketing móvil en Cataluña: mapa de actores, contenidos y tendencias. Pensar La Publicidad. Revista Internacional de Investigaciones Publicitarias, 3(1), 147-162. $\quad$ Retrieved from http://revistas.ucm.es/index.php/PEPU/article/view/16217\nhttp://revistas.ucm.es/index.php/PEPU/article/d ownload/PEPU0909120147A/15362

Statista. (2016). Ranking mundial de los 20 países con más usuarios de Facebook a fecha 2 de marzo de 2016 (en miles). Retrieved from https://es.statista.com/estadisticas/518638/ranking-de-los-20-paises-con-mas-usuarios-de-facebook-a-nivelmundial/

WEF. (2016). The Global Information Technology Report 2016. Geneve: World Economic Forum and INSEAD. Retrieved from http://www3.weforum.org/docs/GITR2016/GITR_2016_full report_final.pdf

WIP. (2013). Estudio de hábitos y percepciones de los mexicanos sobre Internet y diversas tecnologías asociadas. México. Retrieved from http://wip.mx/

World Bank. (2016). Usuarios de Internet (por cada 100 personas). Retrieved from http://datos.bancomundial.org/indicador/IT.NET.USER.P2

\section{Copyrights}

Copyright for this article is retained by the author, with first publication rights granted to the journal.

This is an open-access article distributed under the terms and conditions of the Creative Commons Attribution license (http://creativecommons.org/licenses/by/4.0/). 